\title{
APLIKASI PASAGI (PASAR SUMEDANG GO ONLINE) SOLUSI BELANJA DIMASA PSBB
}

\author{
David Setiadi ${ }^{1}$, Muhamad Nurdin Abdul Muhaemin ${ }^{2}$, Yopi Hidayatul Akbar ${ }^{3}$ \\ CV Binokasih Global Teknologi \\ davidsetiadi1@gmail.com ${ }^{1}$, noordiens89@gmail.com ${ }^{2}$, yopihidayatul.akbar@gmail.com³
}

\begin{abstract}
Abstrak
Berdasarkan PP 21 tahun 2020 tentang Pembatasan Sosial Berskala Besar dalam rangka Percepatan Penanganan Corona Virus Disease (COVID-19) dengan melakukan pembatasan diri dan pergerakan individu warga negara untuk tinggal di rumah, membatasi frekuensi dan jumlah pertemuan massal untuk kemudian dapat menangani penyebaran virus. Beberapa sektor yang tetap diperbolehkan untuk beroperasi diantaranya sektor pangan, kesehatan, logistik, komunikasi, keuangan dan keamanan. Selama PSSB berlangsung, perekonomian mengalami pelemahan baik nasional ataupun regional hal ini dikarenakan kurangnya ruang gerak di sektor perdagangan seperti pasar tradisional maupun pasar modern. Aplikasi pasagi (pasar sumedang go online) merupakan aplikasi bagi masyarakat melakukan transaksi belanja kebutuhan pangan yang tersedia di pasar sumedang secara online sehingga memudahkan masyarakat sumedang untuk berbelanja ke pasar sumedang sehingga mengurangi perkumpulan massal. aplikasi Pasagi menyediakan fitur keranjang belanja, fitur detail pemesanan dan checkout transaksi, serta fitur notifikasi pesanan. Pesanan akan diantar oleh kurir dan dapat melakukan pembayaran ditempat.

Pengembangan aplikasi menggunakan pendekatan prototype yang digunakan dengan model waterfall. Penelitian ini menghasilkan aplikasi pasar online berbasis android dengan menampilkan informasi produk-produk kebutuhan pangan dan dapur yang dijual oleh di pasar sumedang. Dengan aplikasi tersebut, segala transaksi belanja di pasar dapat dengan mudah dilakukan melalui ponsel. Tentunya berbelanja menjadi lebih menarik dan lebih mudah.
\end{abstract}

Kata Kunci : PSBB, aplikasi pasagi, pasar sumedang online

\section{PENDAHULUAN}

\subsection{Latar Belakang}

PSBB atau Pembatasan Sosial Berskala Besar yang diterapkan oleh pemerintah untuk mencegah kemungkinan penyebaran virus covid19 agar tidak semakin meluas. Berdasarkan PP 21 tahun 2020 tentang Pembatasan Sosial Berskala Besar dalam rangka Percepatan Penanganan Corona Virus Disease (COVID-19) dengan melakukan pembatasan diri dan pergerakan individu warga negara untuk tinggal di rumah, membatasi frekuensi dan jumlah pertemuan massal untuk kemudian dapat menangani penyebaran virus. Tetapi ada beberapa sektor yang tetap diperbolehkan untuk beroperasi diantaranya sektor pangan, kesehatan, logistik, komunikasi, keuangan dan keamanan dan sektor lainnya yang berkaitan dengan kebutuhan manusia.

Selama PSSB berlangsung, perekonomian mengalami pelemahan baik nasional ataupun regional hal ini dikarenakan kurangnya ruang gerak di sektor perdagangan seperti pasar tradisional maupun pasar modern. Agar perekonomian tetap stabil dan kebutuhan masyarakat terpenuhi perlu adanya solusi yang mampu mengatasi permasalahan tersebut.

Aplikasi pasagi (pasar sumedang go online) merupakan aplikasi tempat masyarakat belanja kebutuhan pangan yang tersedia di pasar sumedang secara online dan berbasis mobile sehingga mudah untuk digunakan. Aplikasi ini dikembangkan untuk membantu masyarakat dalam menerapakan protokol physical distancing dan juga membantu meningkatkan perekonomian teruatama di sektor perdagangan pasar.

\subsection{Maksud dan Tujuan}

Adapun maksud dan tujuan dari aplikasi pasagi (pasar sumedang go online) diantaranya :

1. Mempermudah masyarakat belanja kebutuhan pangan di pasar sumedang

2. Membantu pemerintah untuk menerapkan protokol sosial distancing selama PSBB berlangsung 


\section{LANDASAN TEORI}

\subsection{Aplikasi}

Jogiyanto (1999:12) Aplikasi adalah penggunaan dalam suatu computer, instruksi (instruction) atau pernyataan (statement) yang disuse sedemikian rupa sehingga computer dapat memproses input menjadi output.

Menurut Shelly, Cashman, Vermaat (2009:57), aplikasi adalah seperangkat instruksi khusus dalam komputer yang dirancang agar kita menyelesaikan tugas-tugas tertentu

\subsection{Pasar}

Mankiw (2007) Pasar adalah sekumpulan pembeli dan penjual dari sebuah barang atau jasa tertentu. Para pembeli sebagai sebuah kelompok yang menentukan permintaan terhadap produk dan para penjual sebagai kelompok yang menentukan penawaran terhadap produk.

Menurut Kotler (2002) Pasar merupakan suatu tempat fisik dimana pembeli dan penjual berkumpul untuk mempertukarkan barang dan jasa.

\section{METODE PENELITIAN}

\subsection{Metodologi}

Metode penelitian yang digunakan dalam mengembangkan aplikasi pasagi (pasar sumedang go online) menggunakan pendekatan prototype dari metodologi yang biasa digunakan pada pengembangan perangkat lunak. Model yang biasa digunakan dalam pengembangan perangkat lunak adalah model waterfall. Tahapan-tahapan mode waterfall diantaranya :

1. Requirement Gathering and Analysis, mengumpulkan dan mendefinisikan kebutuhan yang harus dipenuhi oleh program yang dibangun.

2. Desain, menentukan alur perangkat lunak hingga algoritma secara detail, sehingga akan menghasilkan sistem secara keseluruhan.

3. Implementasi, tahapan dimana seluruh desain diubah menjadi kode program

4. Integration and Testing, penggabungan modulmodul yang dibuat dan dilakukan pengujian untuk mengetahui apakah software yang dibuat telah sesuai.
5. Operation and Maintenance, instalasi dan proses perbaikan sistem sesuai yang disetujui.

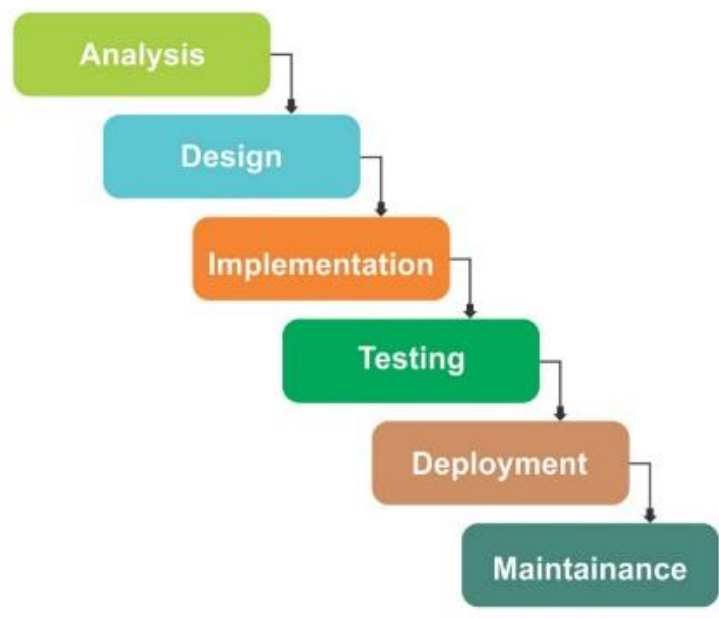

Gambar 3(1) Metode Waterfall

\subsection{Struktur Database}

Struktur database merupakan cara untuk merepresentasikan data didalam aplikasi pasar online pasagi sebagai berikut :

Tabel 3(2) Struktur database

\begin{tabular}{|c|c|c|c|c|c|}
\hline Table & Rows & Type & Collation & Size & Overhead \\
\hline area & 17 & InnoDB & latin1_swedish_ci & $16.0 \mathrm{KiB}$ & \\
\hline bank & 1 & MyISAM & latin1_swedish_ci & $2.0 \mathrm{KiB}$ & 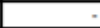 \\
\hline banner & 2 & MyISAM & latin1_swedish_ci & $2.1 \mathrm{KiB}$ & - \\
\hline blog & 6 & InnoDB & latin1_swedish_ci & $64.0 \mathrm{KiB}$ & 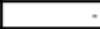 \\
\hline cara_bayar & 1 & MyISAM & latin1_swedish_ci & $2.8 \mathrm{KiB}$ & $580 \mathrm{~B}$ \\
\hline company & 1 & InnoDB & latin1_swedish_ci & $16.0 \mathrm{KiB}$ & 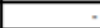 \\
\hline featured & 7 & InnoDB & latin1_swedish_ci & $32.0 \mathrm{KiB}$ & \\
\hline info & 1 & MyISAM & latin1_swedish_ci & $2.4 \mathrm{KiB}$ & $148 \mathrm{~B}$ \\
\hline kategori & 13 & InnoDB & latin1_swedish_ci & $16.0 \mathrm{KiB}$ & - \\
\hline komentar & $\theta$ & InnoDB & latin1_swedish_ci & $64.0 \mathrm{KiB}$ & 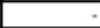 \\
\hline konfirmasi_pembayaran & 2 & InnoDB & latin1_swedish_ci & $16.0 \mathrm{KiB}$ & - \\
\hline kontak & 2 & InnoDB & latin1_swedish_ci & $16.0 \mathrm{KiB}$ & 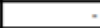 \\
\hline kota & 501 & InnoDB & latin1_swedish_ci & $64.0 \mathrm{KiB}$ & - \\
\hline kurir & 4 & MyISAM & latin1_swedish_ci & $2.2 \mathrm{KiB}$ & $32 \mathrm{~B}$ \\
\hline login_attempts & $\theta$ & InnoDB & utf8_general_ci & $16.0 \mathrm{KiB}$ & - \\
\hline ongkir & 3 & InnoDB & latin1_swedish_ci & $16.0 \mathrm{KiB}$ & F \\
\hline ongkir_area & 199 & InnoDB & latin1_swedish_ci & $16.0 \mathrm{KiB}$ & 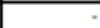 \\
\hline produk & 1,259 & MyISAM & latin1_swedish_ci & $268.3 \mathrm{KiB}$ & $172 \mathrm{~B}$ \\
\hline provinsi & 34 & InnoDB & latin1_swedish_ci & $16.0 \mathrm{KiB}$ & - \\
\hline slider & 2 & InnoDB & latin1_swedish_ci & $16.0 \mathrm{KiB}$ & 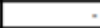 \\
\hline subkategori & 131 & MyISAM & latin1_swedish_ci & $11.8 \mathrm{KiB}$ & 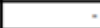 \\
\hline tracking & 157 & InnoDB & \begin{tabular}{|l|} 
latin1_swedish_ci \\
\end{tabular} & $16.0 \mathrm{KiB}$ & . \\
\hline transaksi & 190 & InnoDB & latin1_swedish_ci & $96.0 \mathrm{KiB}$ & - \\
\hline transaksi_detail & 1,619 & InnoDB & latin1_swedish_ci & $144.0 \mathrm{KiB}$ & - \\
\hline users & 653 & InnoDB & utf8_general_ci & $304.0 \mathrm{KiB}$ & . \\
\hline users_group & 4 & InnoDB & latin1_swedish_ci & $16.0 \mathrm{KiB}$ & \\
\hline 26 tables & 4,809 & MyISAM & latin1_swedish_ci & $1.2 \mathrm{MiB}$ & $932 \mathrm{~B}$ \\
\hline
\end{tabular}




\section{IMPLEMENTASI}

\subsection{Implementasi}

Penelitian ini menghasilkan aplikasi pasar online berbasis android dengan menampilkan informasi produk-produk pangan yang dijual oleh di pasar sumedang. Tampilan aplikasi android pasar online

\section{a. Tampilan login}

Untuk dapat menggunakan aplikasi pasar online sumedang, pengguna diwajibkan untuk login menggunakan username dan password yang telah didaftarkan.

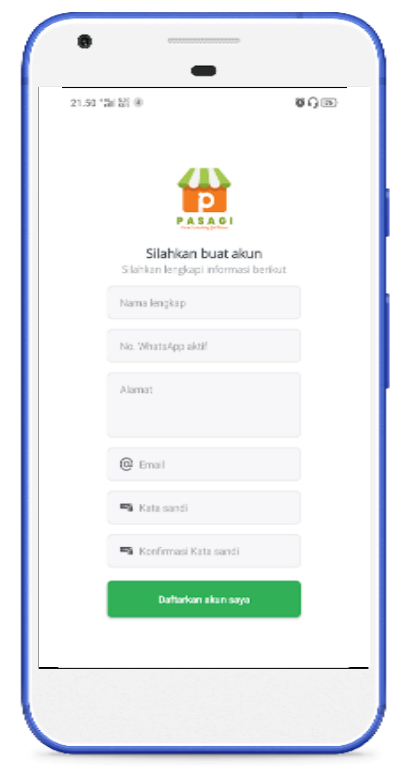

Gambar 4(1) Tampilan Login

\section{b. Tampilan beranda}

Tampilan beranda pada aplikasi pasar sumedang online menampilkan kategori produk pasar.

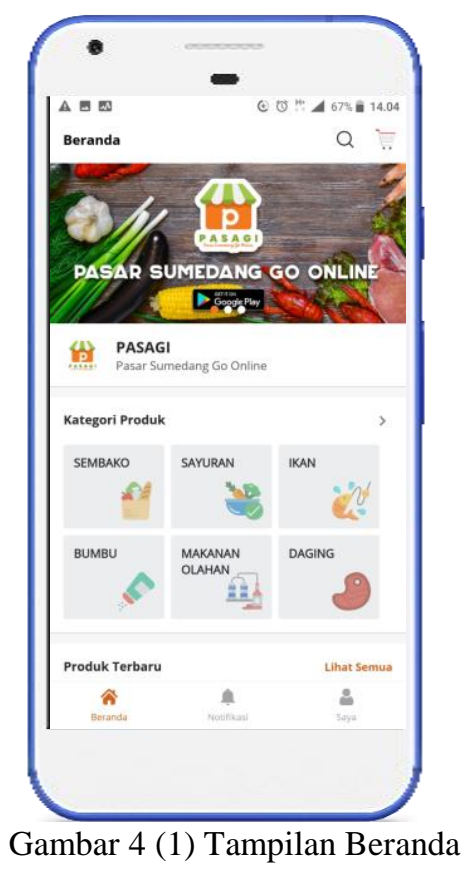

\section{c. Tampilan produk}

Menampilkan produk dengan informasi berupa gambar produk, nama produk harga dan tombol tambah keranjang.

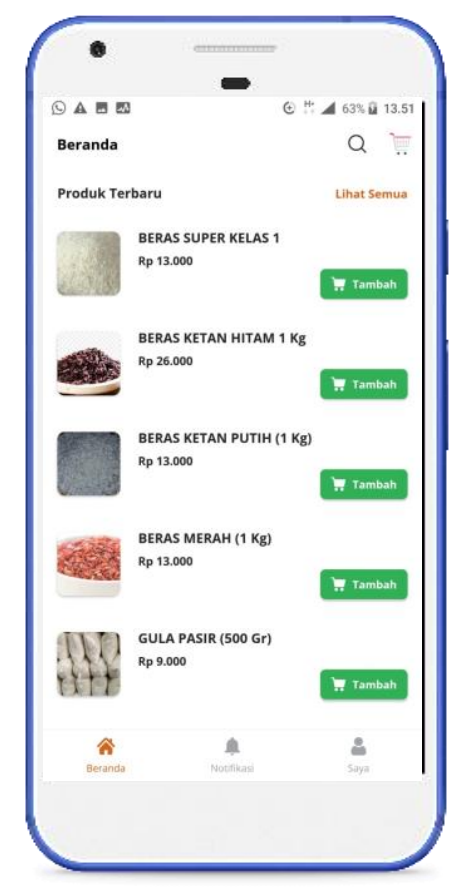

Gambar 4 (2) Tampilan Produk 


\section{d. Tampilan Keranjang}

Produk yang ditambahkan ke keranjang akan tampil di keranjang belanja untuk seterusnya melakukan checkout.

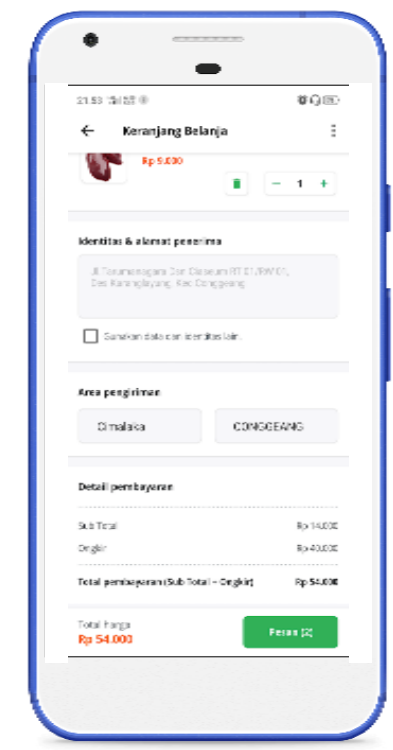

Gambar 4 (3) Tampilan Keranjang

\section{e. Tampilan Detail Pemesanan}

Aplikasi dapat menampilkan info pesanan, alamat pemesan, total bayar dll.

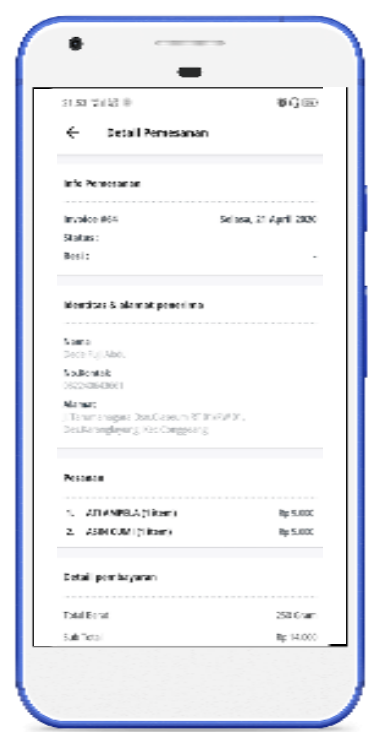

Gambar 4(4) Tampilan Detail Pemesanan

\section{f. Tampilan Dashboard Admin}

Dashboard admin digunakan untuk mengelola data dan informasi yang ditampilkan di aplikasi pasagi. (gambar pada lampiran)

\section{KESIMPULAN DAN SARAN}

\subsection{Kesimpulan}

Aplikasi pasagi (pasar sumedang go online) menjadi salah satu media online yang digunakan masyarakat untuk melakukan transaksi pembelian kebutuhan pangan dan dapur dari pasar sumedang diantaranya sembako, sayuran, ikan, daging, bumbu dan kebutuhan pangan lainnya. Pembelian produk dilakukan secara online dan dikirimkan oleh kurir dan pembayaran dapat dilakukan di tempat setelah pesanan sampai ke pelanggan sehingga memudahkan masyarakat dalam memenuhi keperluannya.

Selain itu, aplikasi pasagi dapat membantu mengurangi penyebaran virus corona selama PSBB berlangsung. Dengan aplikasi pasagi tersebut, segala transaksi belanja di pasar dapat dengan mudah dilakukan melalui ponsel. Tentunya berbelanja menjadi lebih menarik dan lebih mudah.

Aplikasi ini sudah didaftarkan Hak Cipta di Direktorat Jenderal Kekayaan Intelektual (DJKI) Kementrian Hukum \& HAM RI dengan nomor EC00202016985.

\subsection{Saran}

Aplikasi pasagi (pasar sumedang go online) diharapkan pada pengembangan selanjutnya ditambahkan fitur metode pembayaran dan media dalam pembayaran transaksi online seperti transfer bank, e-money, dan media pembayaran transaksi online lainnya.

\section{DAFTAR PUSTAKA}

Billah, Ersandi.2019. Pengertian dan Tahap Metode SLDC Waterfall.

https://medium.com/@ersandibillah03/sdlcwaterfall-3a3c893be77b (diakses tanggal 29 Agustus 2020) 
Hestanto.2017. Teori Pasar Menurut Para

Ahli. https://www.hestanto.web.id/pasar/

(diakses tanggal 29 Agustus 2020)

Pengetahuan, Seputar.2016 Pengertian Aplikasi

Menurut Para Ahli.

https://www.seputarpengetahuan.co.id/2016/06/

10-pengertian-aplikasi-menurut-para-ahli-

lengkap.html (diakses tanggal 19 Oktober

2020)

Pendidikan ,Dosen.2014 Pengertian Pasar

Menurut Para Ahli.

https://www.dosenpendidikan.co.id/pengertianpasar/ (diakses tanggal 19 Oktober 2020) 


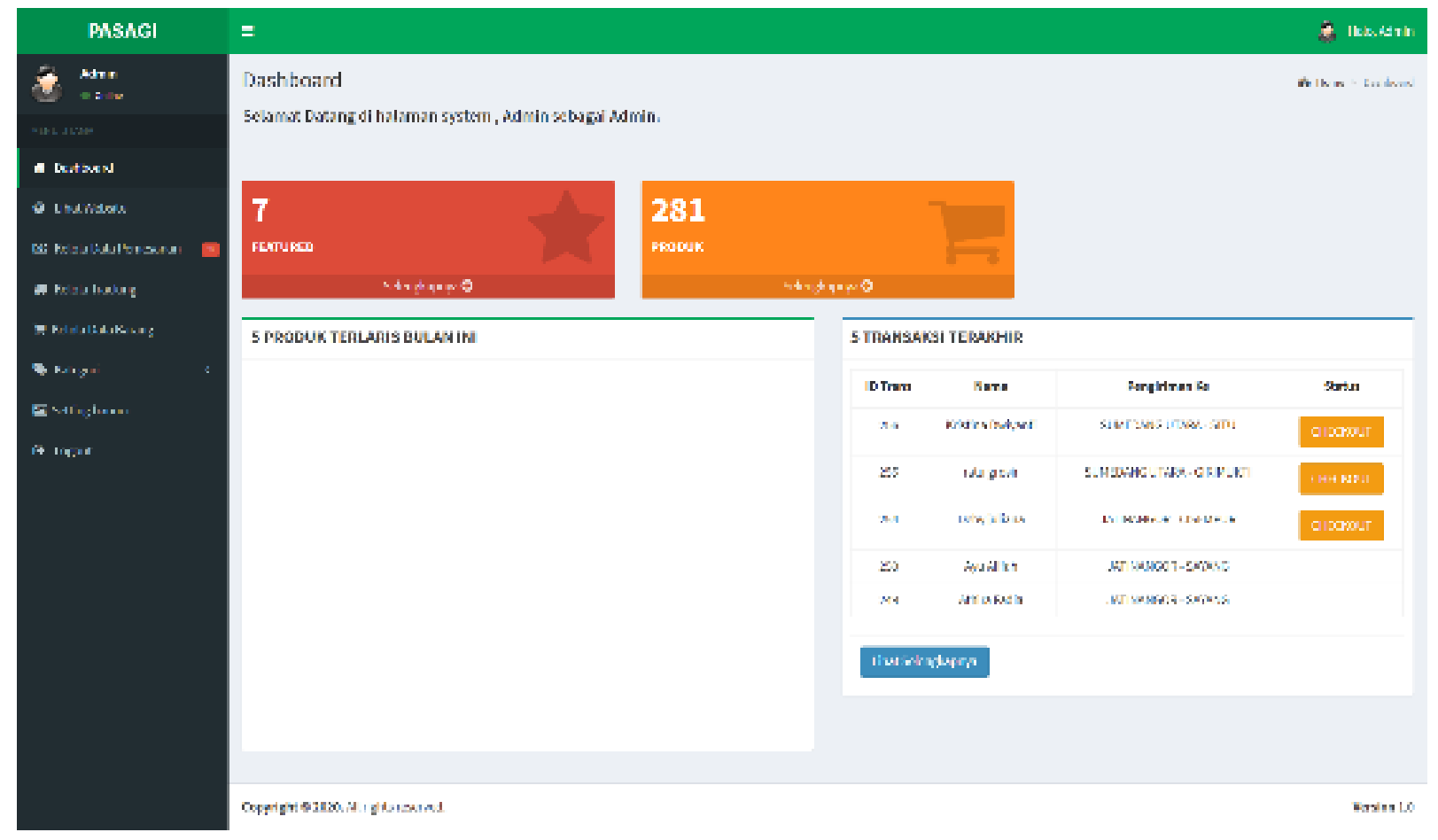

Gambar 4(6) Dashboard Admin 